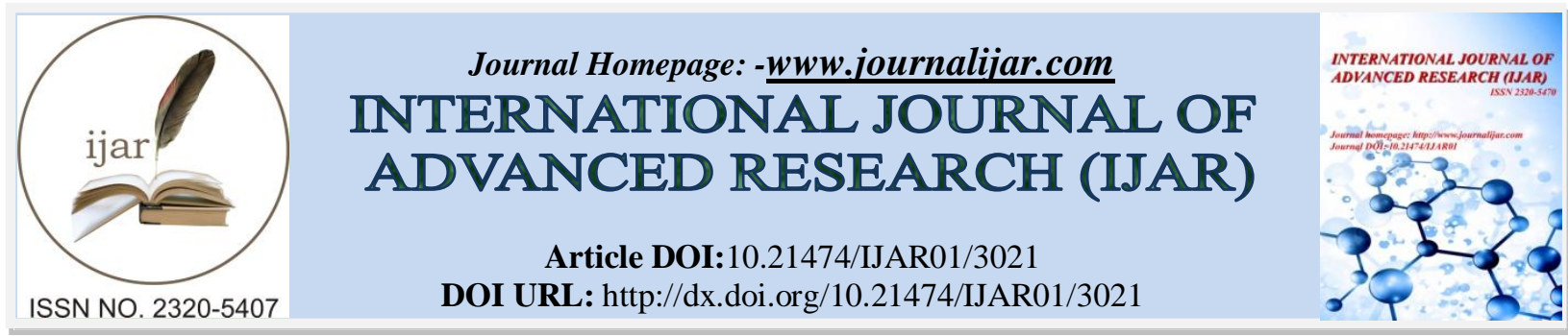

RESEARCH ARTICLE

\title{
DEVELOPMENT OF CHAPPATI, A LOW COSTTRADITIONAL INDIAN FOOD, USING COMMON INGREDIENTS IN DIFFERENT COMPOSITION -A COMPARATIVE STUDY.
}

Antara Roy and Sarmistha Chakrabarti.

Viharilal College of Home Science, Kolkata, India.

\section{Manuscript Info}

Manuscript History

Received: 29 November 2016

Final Accepted: 27 December 2016

Published: January 2017

Key words:-

Low cost supplementary ingredients,

Chappati, Malnutrition, Sensory

evaluation

\section{Abstract}

Background:Chappati, $a$ low cost supplementary traditional food in India, is often used as a supplementary food. However, its nutritional quality depends on the composition of ingredients.Therefore, astudy to be conducted to develop a low cost nutritionally rich and acceptable chappati, for use of the common people.

Objective: To develop chappati with same ingredients of different composition in order to make the most nutritionally rich chappati at low cost and acceptable for consumption.

Design: An experimental study (a comparative nutritional analysis).

Setting: Laboratory based on Viharilal College of Home Science.

Subjects \& Methods:Chappati was prepared by mixing low cost ingredients such as- Bajra (pearl millet) Flour, Soya bean Flour, Sesame seeds, Groundnut Flour, Rice Flour in three different proportions and marked as 1, 2, and 3. Nutrient contents (carbohydrate, protein, fat and iron) of these products and the raw samples were analyzed. Sensory evaluations of the products are carried out for determining the acceptability. Protein quality of these products was evaluated.

Results: Nutritional analysis indicated that all the products were rich in carbohydrate and protein. But comparison showed that product- 3 was rich in protein and iron. Protein quality of product-3 found to be highest.

Conclusion: Product Sample-3(proportion-3) was found to be nutritionally richest in terms of the nutrients analyzed. It may be used to provide adequate nutrients andcan be used as a protein supplement.

Copy Right, IJAR, 2016,. All rights reserved.

\section{Introduction:-}

The word "Supplementation" is derived from the word "Supplement" which means something or any nutrient is added to the food to improve the quality of food and the process of making up for a deficiency, especially any nutrient deficiency [1]. 


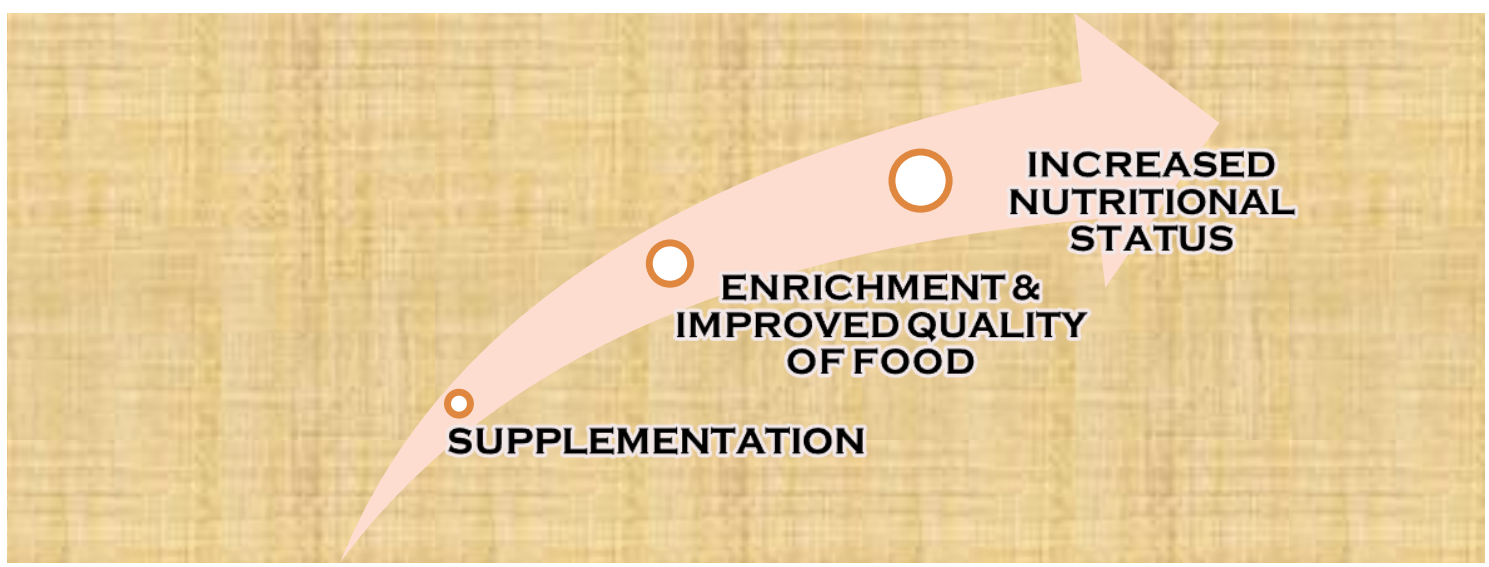

The food which are low in cost and rich in nutrients in adequate amounts as compared to the high cost nutrient rich food. Impact of low cost food supplementation on the child growth, merits careful evaluation, in the view of reliance of many States and non-governmental organizations on this intervention to improve child health in Low \& Middle Income Countries(LMIC)[2].

Bajra,Soyabean,Sesame seed, Groundnut,Rice -All the low cost ingredients are rich in adequate amount of carbohydrate, protein, fat, vitamins \& minerals(specially iron)[3].

Previous study reported that,two type of ready to eat supplementary food formulations were developed by roller drying based on wheat, soy protein concentrate, whey protein concentrate, and green gram flour and was fortified with vitamins and minerals to meet the one third of the recommended daily allowance (RDA). However, the formulations were nutritionally better than only cereal based supplementary food formulations available commercially. The product could be served in the form of porridge with water/milk or in the form of small chappati $[4]$.

Another study reported that, onfortified spreads peanut can be used as supplementary foods instead; these are energy-dense, lipid-based pastes with added powdered micronutrients [5].

\section{Objectives:-}

* To compare the nutritive value among the three proportions taken as sample.

* To compare the nutritive value of raw \& cooked product of the sample ingredients of three proportions.

* To evaluate the acceptability rate of three products made by three proportions among the community.

* To evaluate the quality of protein among three proportions.

* To develop chappati with same ingredients of different composition in order to make the most nutritionally rich chappati at low cost and acceptable for consumption.

\section{Materials \& Methods:-}

At first, all the raw materials were grounded into powdered form. These were mixed in three different proportions are as follows-

\begin{tabular}{|c|c|c|c|}
\hline INGREDIENTS & PROPORTION-1 & PROPORTION-2 & PROPORTION-3 \\
\hline Bajra & 20 gram & 30 gram & 10 gram \\
\hline Soya bean & 20 gram & 30 gram & 30 gram \\
\hline Sesame & 20 gram & 20 gram & 40 gram \\
\hline Groundnut & 20 gram & 10 gram & 10 gram \\
\hline Rice & 20 gram & 10 gram & 10 gram \\
\hline
\end{tabular}

Then chappatis were prepared from these three proportions according to conventional method.

\section{Carbohydrate Estimation Method:-}

Anthrone Method-100 mg sample was weighed into a boiling tube. It washydrolyzed by keeping it on boiling water bath for three hours with $5 \mathrm{ml}$ of $2.5 \mathrm{~N} \mathrm{HCL}$ and cooled to room temperature. After that it was neutralized with sodium carbonate until the effervescence ceased. The volume was made up to $200 \mathrm{ml}$ with distilled water and 
centrifuged at 3000R.P.M for 15 minutes. Then supernatant was collected and $1 \mathrm{ml}$ aliquot was taken for analysis. Then $4 \mathrm{ml}$ of anthrone reagent was added andheated for eight minutes in a boiling water bath, cooled rapidly and green colour appeared. The reading was taken at 630nm in spectrophotometer (Parkin Elmer lambda 25) [6].

\section{Protein Estimation Method:-}

Lowry Method- $0.4 \mathrm{gm}(400 \mathrm{mg}$ ) sample was taken in $20 \mathrm{ml}$ buffer solution(Measured the $\mathrm{pH}$ at 7.6). Then it was homogenized \& kept overnight for extracting protein. Then cold centrifuged for 20 minutes at 5000 R.P.M (Rate per Minute).Then $1 \mathrm{ml}$ supernatant was collected. After that $5 \mathrm{ml}$ of Lowry reagent was added \& allowed to stand for 10 minutes. Then $0.5 \mathrm{ml}$ Folin's reagent was added \& kept it for 30 minutes. The reading was taken at $630 \mathrm{~nm}$ in spectrophotometer ( Parkin Elmer lambda 25) [7].And protein quality also measured by using NDP calorie\%.

Fat Estimation Method:-

Soxhlet Extractor Method- At first, $5 \mathrm{gm}$ dried sample was taken. Covered it tightly by the filter paper \& wrapped by string. $100 \mathrm{ml}$ petroleum ether was taken in a round bottom flask. The sample was placed in the extractor of the soxhlet apparatus and it wasrun for at least 16 hours. After complete extraction of fat from the sample, the solvent was poured into a weighed Petridish and the ether was evaporated. Then the final weight of fat containing Petridis was taken. Thus the amount of fat was estimated [8].

\section{Iron Estimation Method:-}

At first $500 \mathrm{mg}$ sample was taken in a $25 \mathrm{ml}$ volumetric flask.Then $10 \mathrm{ml}$ nitric acid was added\& kept for overnight.Then it was heated for 6 hours. Then $2 \mathrm{ml}$ per-chloric acid was added \& again heated for until the sample became transparent liquid.Then the volume make up with the double distilled water and filtered. Then reading was taken by atomic absorption spectrophotometer [9]. 
Results:-dFigure.1:-Nutritional evaluation of three different proportions and their products

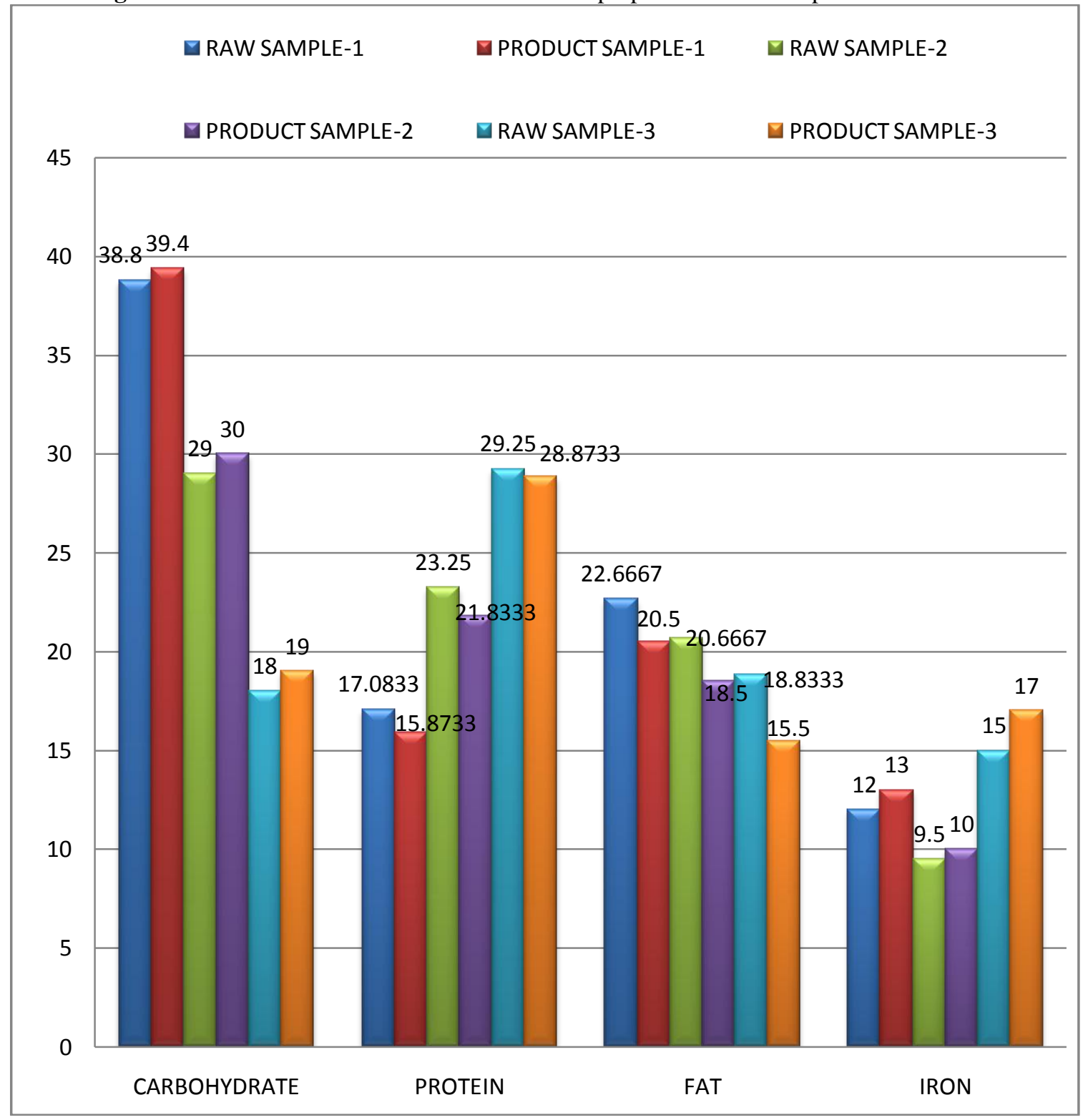

According to figure, in $100 \mathrm{~g}$ sample, carbohydrate content of raw sample-1,2,3 were $38.8 \%, 29 \%, 18 \%$.Carbohydrate content of product sample-1,2,3 were $39.4 \%, 30 \%, 19 \%$.Protein content of raw sample-1,2,3 were $17.08 \%, 23.25 \%, 29.25 \%$.Protein content of product sample-1,2,3 were $15.87 \%, 21.83 \%, 28.87 \%$.Fat content of raw sample-1,2,3 were $22.66 \%, 20.66 \%, 18.83 \%$.Fat content of product sample-1,2,3 were $20.5 \%, 18.5 \%, 15.5 \%$.Iron content of raw sample-1,2,3 were $12 \%, 9.5 \% 15 \%$.Iron content of product sample-1,2,3 were $13 \%, 10 \%, 17 \%$. 
Figure.2:- Sensory evaluation of three different proportions and their products

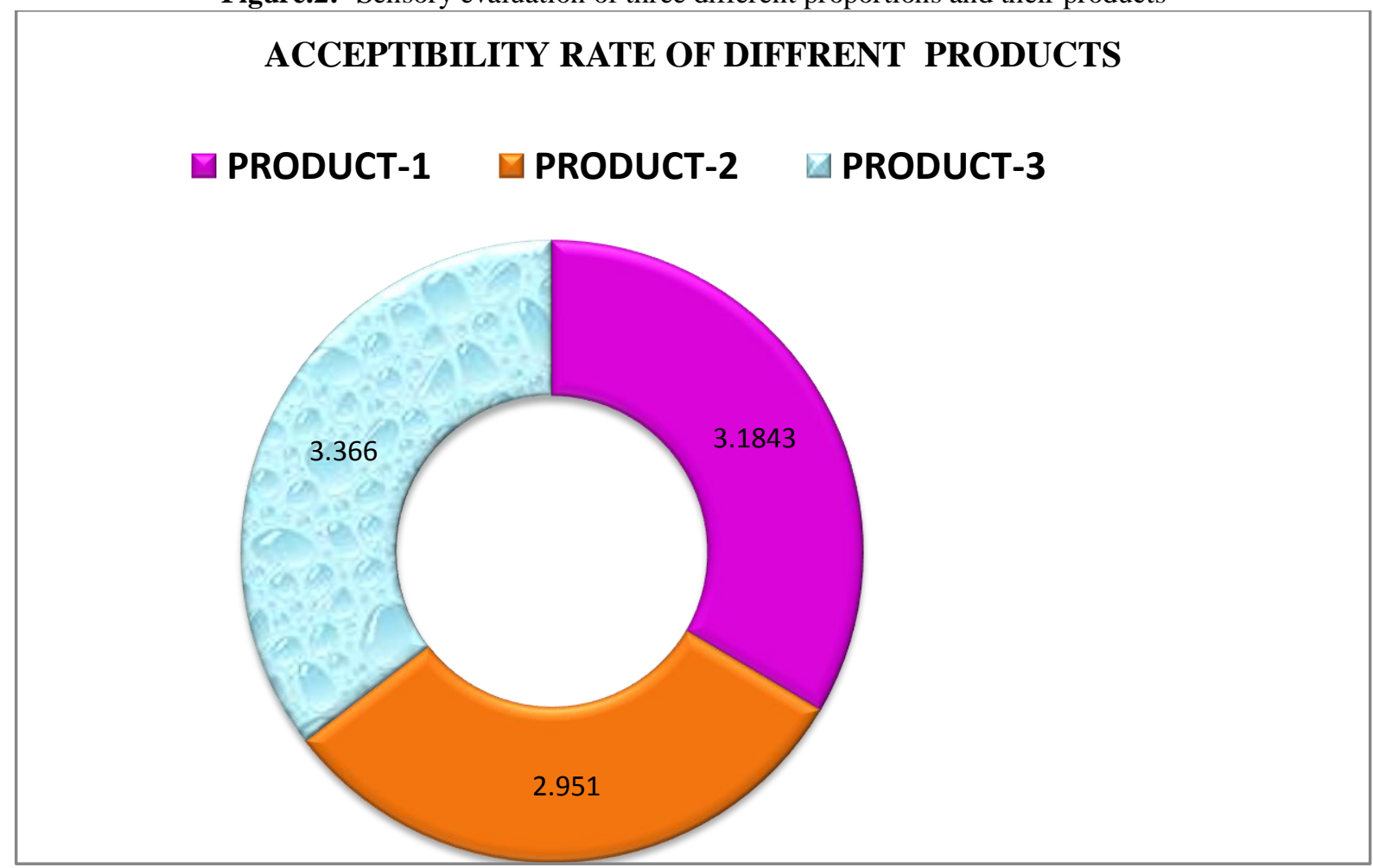

According to figure, acceptability rate of product-1,2,3 were $3.18 \%, 2.95 \%, 3.36 \%$.

Figure.3:- Protein quality estimation of three products made by three different proportions

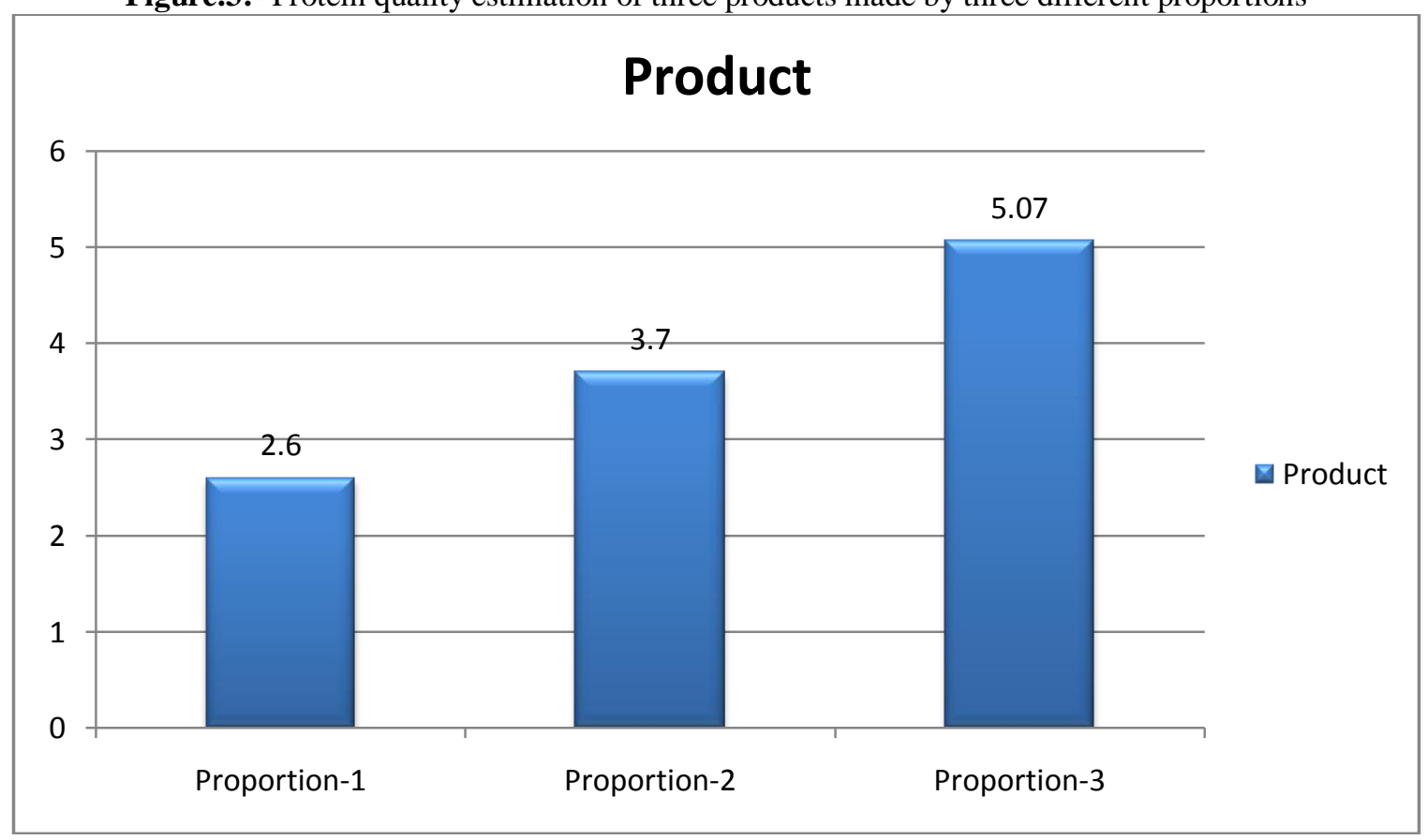

According to figure, protein quality of product-1,2,3 were $2.6 \%, 3.7 \%, 5.07 \%$. 


\section{Discussion:-}

Fig-1 shows that the carbohydrate content of three mixes were slightly increased after cooking.Protein content of three mixes were decreased after cooking. Fat content of all the mixes were decreased after cooking, but among them fat content of raw sample-3 is highly decreased.Iron content of all the mixed are increased after cooking.

Fig -2 shows that acceptability rate of product sample-3 is highest among the three different mixed.

Fig $\mathbf{- 3}$ shows that protein quality of product-3 was highest among three products.

Studies have shown that, for adults, diets with an NDP Cal\% of 5\% would be adequate to maintain health. According to this study while the quantity of all the three products were comparable, product- 3 was most suitable for adultsin terms of protein quality.

\section{Conclusion:-}

The studywas based on nutritional evaluation of the low cost food (chappati)that can be used as supplementary food.

Among all the three products developed,protein and iron contents were found to be highest in one of the products. Moreover, quality of the protein in this product also was found to be highest.

Therefore, this particular product (chapppati) is most suitable as a supplementary food among the three products developed.

\section{Aknowledgement:-}

I sincerely acknowledge the Dep't of Home Science, Calcutta University for permitting me to do the experiment

\section{Financial Support: None.}

Conflict of Interest: None declared.

\section{Reference:-}

1. B. Srilaksmi (2010). Title of work: Food science. Location: New Age International (p) Ltd., New Delhi-110002

2. Manning, Katie, Ruth Pelling, Tom Higham, Jean-Luc Schwenniger and Dorian Q Fuller.4500-year-old domesticated pearl millet (Pennisetumglaucum) from the Tilemsi Valley, Mali: new insights into an alternative cereal domestication pathway. Journal of Archaeological Science .2010; 38 (2): 312-322

3. B. Srilaksmi (2010). Title of work: Food science. Location: New Age International (p) Ltd., New Delhi-110002

4. Haas, J. D., \&Brownlie, T. Iron deficiency and reduced work capacity: a critical review of the research to determine a causal relationship. The Journal of nutrition.2001;131(2), 676S-690S.

5. Hinton, P. S., Giordano, C., Brownlie, T., \& Haas, J. D. Iron supplementation improves endurance after training in iron-depleted, nonanemic women. Journal of Applied Physiology.2000;88(3), 1103-1111.

6. Strom, B. L.; Schinnar, R; Ziegler, EE; Barnhart, KT; Sammel, MD; MacOnes, GA; Stallings, VA; Drulis, JM; et al. Anthrone method. JAMA: the Journal of the American Medical Association (American Medical Association).2001;286 (7): 807-814.

7. Tarnopolsky, M. Lowry method: a critical experiment.Journal of biochemical method.1998;8(4), 286-297.

8. Sohani, Mehdi.Soxhlet extractor for fat .2013; (2): 239-247.Retrieved February 2, 2014.

9. Oplinger, T.M.; Oelke, E.A.; Kelling, K.A.; Doll, J.D. iron estimation method, New Center, Purdue University.1991. Retrieved 26 September 2015. 